RESEARCH ARTICLE

\title{
Diversity and Conservation of Waterbirds in the Northern Avifaunal Region of Sri Lanka
}

\author{
Chaminda S. Wijesundara ${ }^{1, *}$, Deepal Warakagoda ${ }^{2}$, Udaya Sirivardana ${ }^{2}$, Dilan Chathuranga ${ }^{1}$, Tharangi \\ Hettiarachchi $^{1}$, Nuwanthika Perera ${ }^{3}$, Packiyanathan Rajkumar ${ }^{4,5}$, Saumya Wanniarachchi ${ }^{1}$ and Gayani \\ Weerakoon $^{1}$
}

${ }^{1}$ Department of Zoology, University of Peradeniya, Peradeniya, Sri Lanka.

${ }^{2}$ Ceylon Bird Club, 127 Nawala Road, Colombo 5, Sri Lanka.

${ }^{3}$ Department of Biological Sciences, Wichita State University, Wichita, Kansas, U.S.A.

${ }^{4}$ Divisional Secretariat, Chundukkuli, Jaffna, Sri Lanka.

${ }^{5}$ Postgraduate Institute of Science, University of Peradeniya, Peradeniya, Sri Lanka.

Received: 31/08/2016; Accepted: 29/06/2017

\begin{abstract}
The aim of the present study is to evaluate the waterbird diversity, distribution, and conservation status in the northern avifaunal region of Sri Lanka, which includes two of the four richest waterbird regions in Sri Lanka, namely Jaffna and Mannar. We compiled data from the annual waterbird censuses and monthly records of the Ceylon Bird Club from 2011 to 2017 and from a systematic survey carried out by us from October 2014 to March 2016.

We recorded a total of 116 species of waterbirds belonging to 23 families. Among them are species confined to the northern region including the rare breeding residents the Crab Plover (Dromas ardeola), Indian Courser (Cursorius coromandelicus), Spot-billed Duck (Anas poecilorhyncha), and Saunders's Tern (Sternula saundersi). The Greater Flamingo (Phoenicopterus roseus), which is now uncommon elsewhere in Sri Lanka, was recorded in high numbers. The Spot-billed Duck, which was a very rare migrant to Sri Lanka until recently, was found to have established breeding populations in the region. The Glossy Ibis (Plegadis falcinellus) and Comb Duck (Sarkidiornis melanotos), which are extirpated breeding residents in Sri Lanka, were recorded as part of the migrant population. The Common Coot (Fulica atra), which was previously considered a very rare breeding resident, was found to be abundant with over 1,000 individuals in some localities.
\end{abstract}

Keywords: Waterbirds, diversity, northern avifaunal region, conservation, wetlands.

\section{INTRODUCTION}

\section{Bird diversity in the South Asian region}

At present, of the 10,000 or more known species ofbirds in the world, some 1,800 species are found in the Oriental Region (Clements et al., 2016). The South Asian biogeographical region, defined as Afghanistan, Pakistan, India including the Andamans and Nicobars, Nepal, Bhutan, Bangladesh, Sri Lanka, the Maldives and the Chagos archipelago, forms only a small part of the Oriental Region, but is home to some 1,300 species of birds (approximately 13\% of the world's bird species) (Rasmussen and Anderton, 2012). Of these, some 143 bird species (11\%) are endemic to the South Asian region. Hence, this region is critical for the preservation of avian biodiversity.
Several factors contribute to the avian species richness in the South Asian region. These include altitudinal variation (from sea level up to the Himalayas, the world's tallest mountain range), variability in climate and associated vegetation diversity, and its geographical location within the major Central Asian migrant flyway. The region is close to two other biogeographic provinces (Palearctic and Afrotropical or Ethiopian), which has resulted in species from these two regions extending their ranges into the South Asian region. Most species in the region are Oriental (IndoMalayan) species, typified by minivets and ioras; some are Palearctic species, including accentors, and a small number originate in Africa and these include creepers.

\section{Bird diversity in Sri Lanka}

Sri Lanka is a tropical island $\left(65,610 \mathrm{~km}^{2}\right)$ located south of India $\left(5^{\circ} .55^{\prime}-9^{\circ} .55^{\prime} \mathrm{N}, 79^{\circ} .42^{\prime}-81^{\circ} .52^{\prime} \mathrm{E}\right)$. At present 454 bird species belonging to 20 orders have been recorded from Sri Lanka. Of these, 238 are breeding residents ${ }^{1}, 144$ are regular migrants ${ }^{2}$, and 72 are vagrants ${ }^{3}$ (Warakagoda et al., 2012). The majority of migrant species arrive in Sri Lanka from northern latitudes. A large number of migrant species are waterbirds (Warakagoda and Sirivardana, 2006).

\section{Waterbirds of Sri Lanka}

The Ramsar Convention defines 'waterbirds' as birds 'ecologically dependent upon wetlands'. Waterbirds are important indicators of the ecological condition and productivity of wetland ecosystems (Wei et al., 2009), and are one of the key attributes of the biodiversity of many wetlands. Counts of waterbirds form one of several elements that are used to identify important wetlands. It has been stated that the number of waterbirds using a given wetland is a good indicator of that site's biological importance, e.g. the number of faunal and floral species it can support (Scott, 1980).

Approximately 164 species of waterbirds belonging to 23 families have been identified in Sri Lanka. These birds

1 Species which breed within the territory of the country. 2 Species which are present in the country for some months but

do not breed within the territorial limits of the country. 3 Species recorded irregularly in Sri Lanka. 
are found in a wide variety of wetlands from sea level to an elevation of 2,200 m. Large concentrations are found in the coastal and inland wetlands of Sri Lanka's dry zone. Table 1 gives a list of the families of waterbirds found in Sri Lanka.

The four richest waterbird regions in Sri Lanka are Jaffna, Mannar, Puttalam-Chilaw and the Southern Coastal. In the area demarcated until recently as the South-East Coastal region the destruction of critical feeding and resting wetlands within it for a seaport has caused a drastic fall in the number of waterbirds. This has now been observed throughout several years in the waterbird censuses and at other times. It was thought that therefore it is more apt to enlarge its range and name the new area the Southern Coastal region. (Warakagoda and Sirivardana, 2006, Wei et al., 2009, Price et al., 2014) (Figure 1 and Figure 2).

\section{Aim of the study}

Over the past century researchers have documented significant changes to the actual and known status of several species of waterbirds. The aim of the present study was to evaluate the waterbird diversity and distribution in the northern avifaunal region of Sri Lanka, with the intention of recording areas of high waterbird abundance and high priority conservation areas, especially wetlands. The northern avifaunal region as defined here comprises the area north of a straight line from north of the Wilpattu National Park on the west coast to Nilaveli on the east coast. As a southern boundary cannot be precisely defined meaningfully, with reference to inland water bodies, we consider the use of such a line to be justified. This region includes two of the richest waterbird regions in Sri Lanka, viz. Jaffna and Mannar.

\section{MATERIALS AND METHODS}

We compiled data from 2011 to 2017 obtained from the annual waterbird censuses conducted by the Ceylon Bird Club (Ceylon Bird Club 2011-2017) and the monthly records of the Club (Ibid.), and from a systematic survey carried out from October 2014 to March 2016 by some of us (CW, DC, TH, NP, PR, SW, GW) in parts of the region.

Several factors can significantly affect the data gathered in a waterbird census: the extent of coverage of each region and site, weather conditions, movements of birds among sites, the degree of visibility and the current conditions of the sites, especially including variable water levels.

The annual censuses by the Ceylon Bird Club are coordinated with those in other countries by Wetlands International, and carried out generally following standard guidelines set out by the latter (e.g. Wetlands International 2010), by spot counts in the first two weeks of February during the northern winter migrant season.

The observations by members of the Club published in its monthly journal may be described as random sampling. The club exercises care to maintain a high standard of authenticity in its data, especially in regard to the identification of bird taxa (e.g. Warakagoda and Sirivardana, 2009).

The systematic survey (2014-2016) was done twice a month. Point counts with unlimited distance were used for assessing the diversity and abundance of birds. Observations were made using standard birding binoculars (Nikon $8 \times 40$ Action Extreme and Nikon Monarch 10×42) and a spotting scope (Vixen $25 \times 50$ ). The major sites in Jaffna region included Mandaitivu, Allaipiddy, Mankumban, Melingimunai (Kayts), Kaladaipiddy (Pungudutivu), Delft Island wildlife conservation area, Araly, Ponnalai Bridge area, Kaithady, Thanankilappu, Kopay, Puthur, Sarasalai, Anthanathidal, Kapputhu, Thondaimanaru, Vallai, Mulli, Nagar Kovil, Mamunai, and Chundikkulam National Park. The major sites in Mullaitivu and adjacent areas included Chalei, Nanthikadal, Nayaru, and Kokilai Sanctuary whereas Giant's Tank, Vankalai Sanctuary,

Table 1: Families of waterbirds found in Sri Lanka and the number of species recorded from each family in the northern avifaunal region.

\begin{tabular}{lllc}
\hline Family & $\begin{array}{l}\text { No. of } \\
\text { Species }\end{array}$ & Family & $\begin{array}{c}\text { No. of } \\
\text { Species }\end{array}$ \\
\hline Podicipedidae (grebes) & 1 & Phalacrocoracidae (cormorants) & 3 \\
Anhingidae (darters) & 1 & Pelecanidae (pelicans) & 1 \\
Ardeidae (herons, egrets) & 12 & Ciconiidae (storks) & 4 \\
Threskiornithidae (ibises, spoonbills) & 3 & Phoenicopteridae (flamingos) & 2 \\
Anatidae (ducks) & 10 & Rallidae (rails, crakes, coots) & 6 \\
Jacanidae (jacanas) & 1 & Rostratulidae (painted-snipes), & 1 \\
Haematopodidae (oystercatchers) & 1 & Recurvirostridae (stilts, avocets) & 2 \\
Dromadidae (Crab Plover) & 1 & Burhinidae (stone-curlews, stone- & 2 \\
Glareolidae (coursers, pratincoles) & 3 & plovers) & 9 \\
Scolopacidae (stints, sandpipers, etc.) & 23 & Laridae (gulls) & 5 \\
Sternidae (terns) & 15 & Accipitridae (raptors) & 6 \\
Alcedinidae (kingfishers) & 4 & & \\
\hline
\end{tabular}




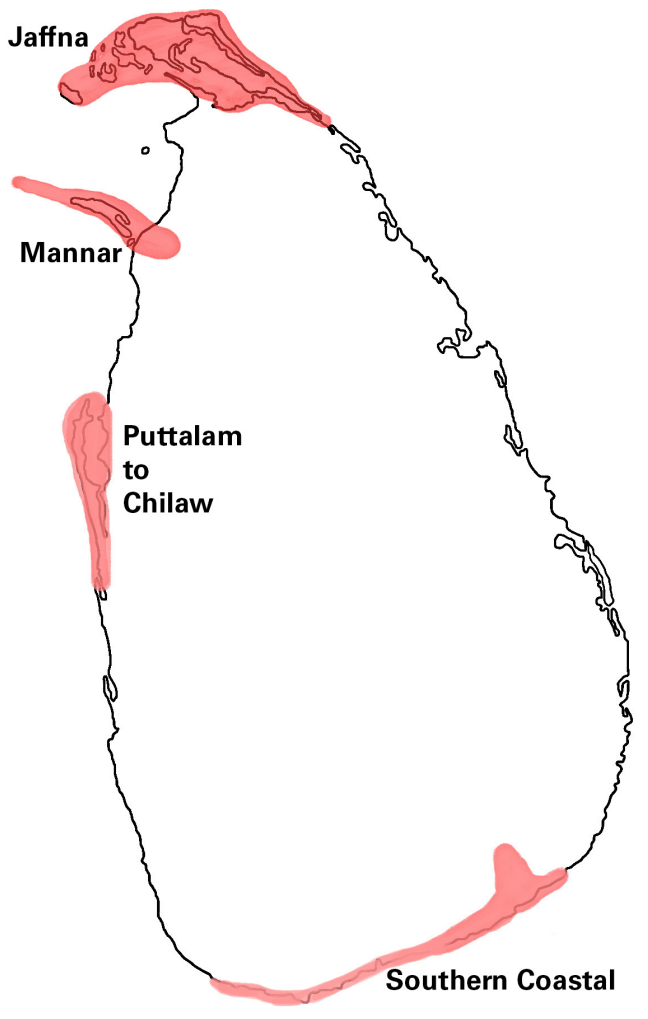

Figure 1: Regions of high waterbird density in Sri Lanka. After Warakagoda and Sirivardana (2006). Map prepared by Chaminda S. Wijesundara.

Erukkulampiddy, Thalaimannar, and Vidaththaltivu were the major sites surveyed in Mannar region (see Figure 3).

Censuses during the systematic survey were conducted between sunrise and sunset of each census day, with peak counting hours between $0630 \mathrm{~h}$ and $1000 \mathrm{~h}$ and $1530 \mathrm{~h}$ and $1800 \mathrm{~h}$. These represent the times when the birds are most active. Each count lasted about 20 minutes. Point transects were established as delineated by Sutherland (2006), Buckland et al. (2001), Marsden (1999), Bibby et al. (2000), and Raman (2003). Each area had a minimum of five point counting stations, each separated from the next by at least $250 \mathrm{~m}$, to minimize double-counting. During the study period, each site was visited multiple times to allow for temporal variation of bird diversity.

To minimize time-of-day bias, each point count station was given an equal chance of visitation during different times of the day, on different counting days. For example, if station 1 was surveyed from $0630-0730 \mathrm{~h}$ on a given day, it was surveyed from 1700-1800 h on another day. By dividing the day into different census sessions (e.g. 0630-0730 h, 0730-0830 h, etc.), it was possible to spend approximately equal amount of sampling time in each session to represent different times of the day during the study period.

\section{RESULTS}

We recorded a total of 116 species of waterbirds belonging to 23 families in the study region (see Appendix 1). Of these, 54 species were migrants, 6 species were mainly migrants with resident populations, another 6 were mainly

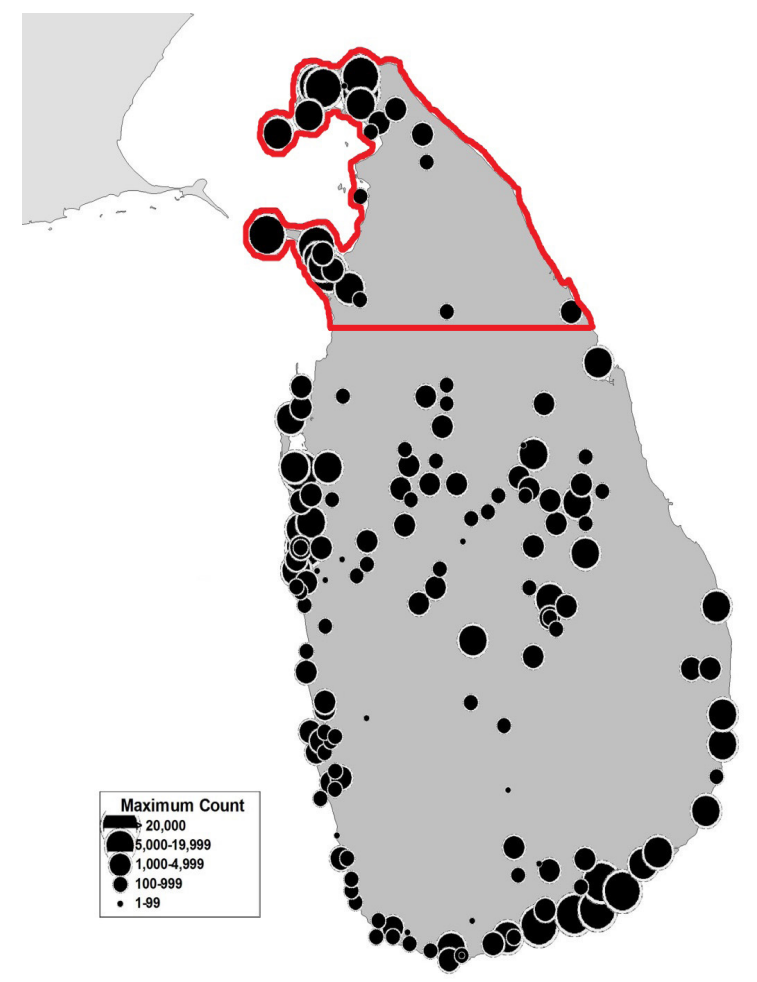

Figure 2: Sites with high density of waterbirds in Sri Lanka 1987-2007. The area covered by the present study, the Northern Avifaunal Region, is highlighted in red. (Source: Wei et al., 2009).

residents with migrant populations, 1 species was mainly a migrant with doubtful resident status, 2 species were mainly residents with doubtful migrant status, and 47 were residents.

The total numbers of individuals in the annual census during this period $(2011$ - 2017) varied from 69,000 to 227,000 . By far the majority of waterbirds were migrants. The most numerous by group were ducks and shorebirds. More than 100,000 waterbirds were seen at a site on four occasions: three times in Mannar, estimated at 200,000 to 500,000, and once 130,000 in Jaffna.

Figure 4 shows the most abundant waterbird species recorded during the systematic survey, whose total counts were over 1,000 and Figure 5 shows the monthly variations in the abundance of these species. The Eurasian Wigeon (Anas penelope) and Brown-headed Gull (Chroicocephalus brunnicephalus), both of which are migrants, showed higher abundances toward the latter part (early 2016). The reason may be higher numbers of migrating individuals making landfall in Sri Lanka that year compared to previous years. Whether the same pattern will follow in the following migrant season should be further investigated. Little Cormorant (Phalacrocorax niger), a resident species, showed an increased abundance in the early part of the systematic survey and another (lower) peak in abundance during the middle part of the survey. Thereafter it was recorded in lower numbers. The reason may have been that most of the population has moved to other parts of its range in Sri Lanka, due to changes in water level patterns.

All eight species of waterbirds in Sri Lanka whose breeding is known to be confined to the northern region were 


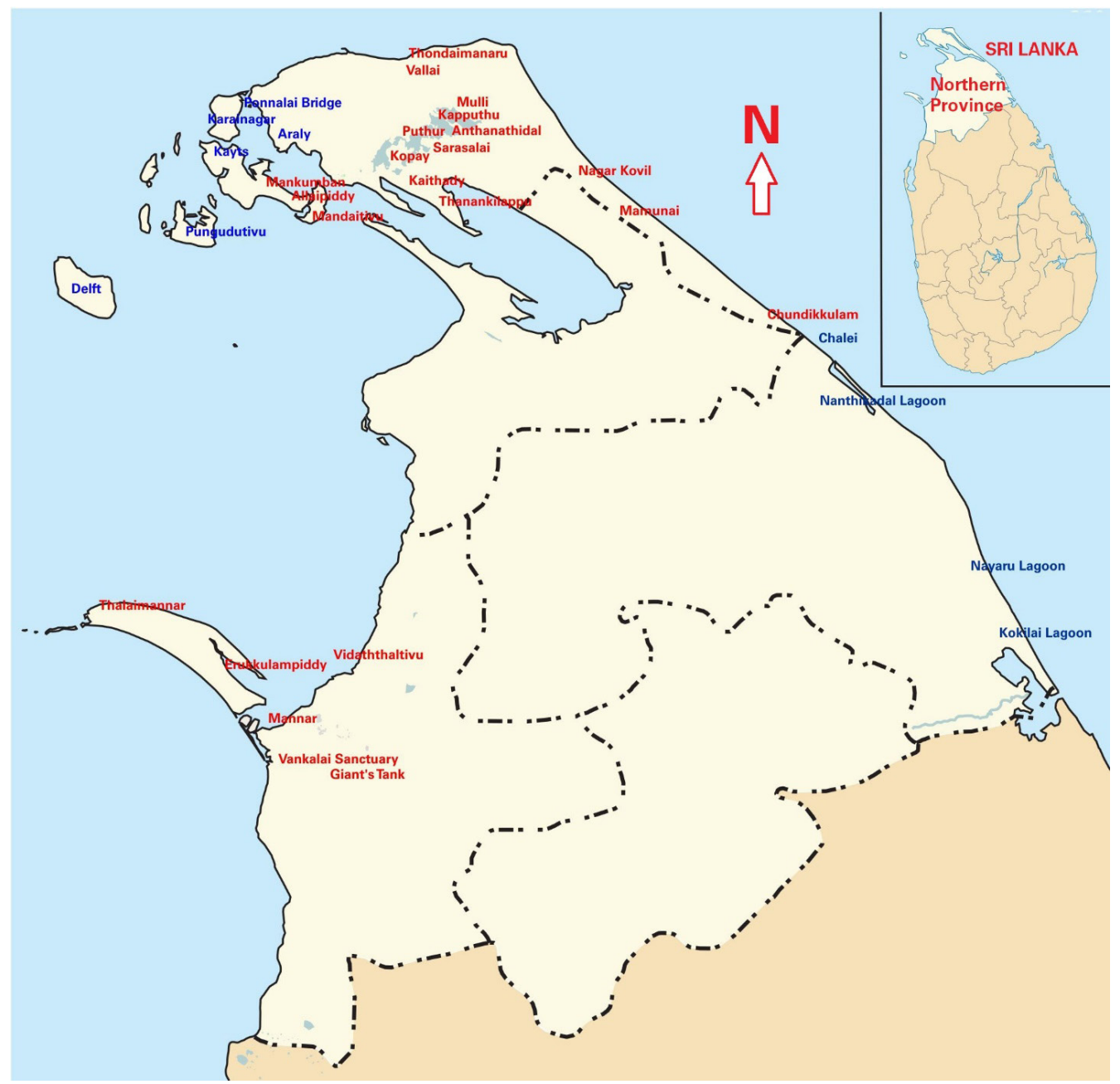

Figure 3: Systematic survey 2014-2016. Major sampling areas in the Northern Province. Map prepared by Chaminda S. Wijesundara.

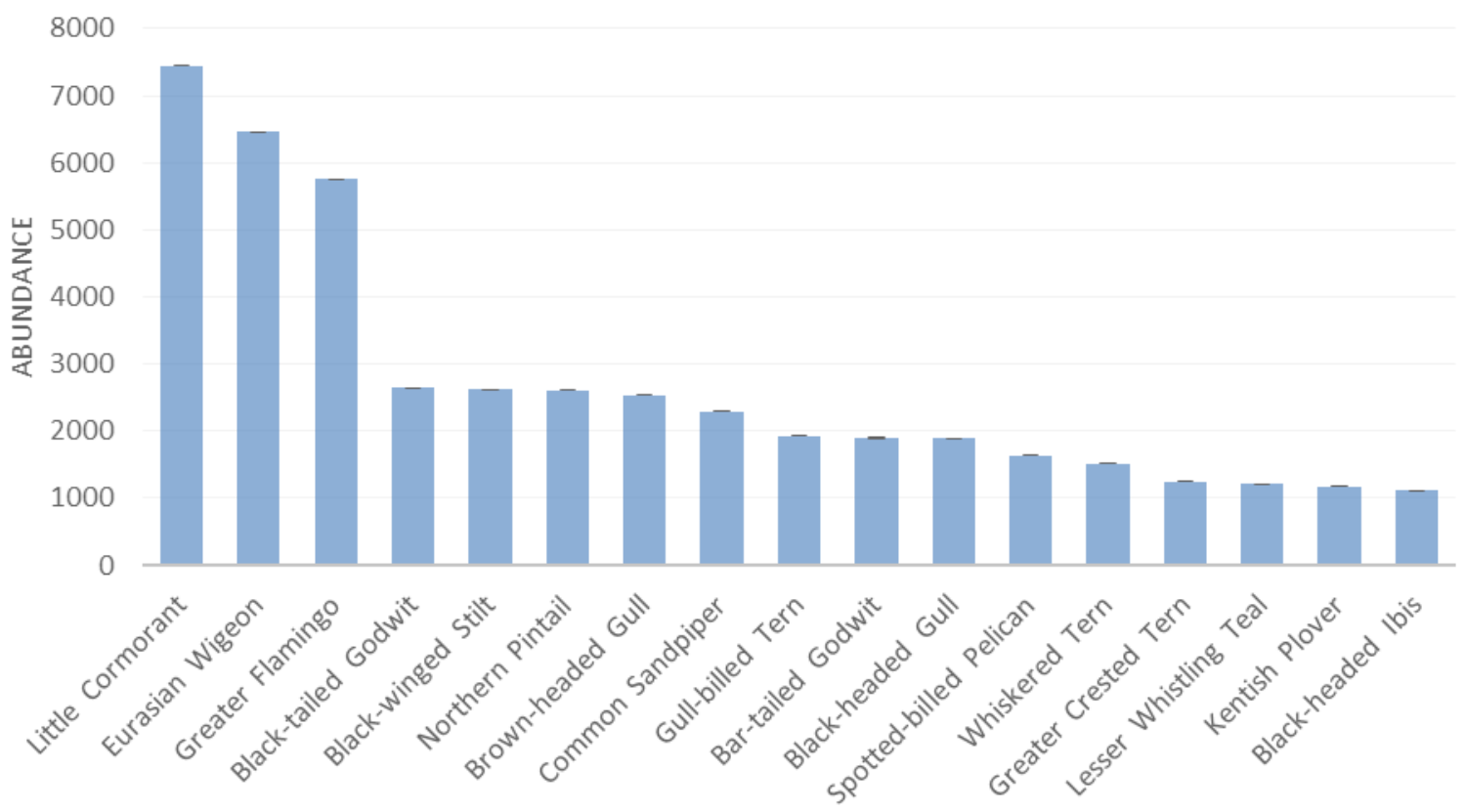

SPECIES

Figure 4: Systematic survey 2014-2016. Abundance of the most common waterbird species in the present study area (including Mandaitivu, Allaipiddy, Mankumban, Melingimunai [Kayts], Kaladaipiddy [Pungudutivu], Delft Island wildlife conservation area, Araly, Ponnalai Bridge area, Kaithady, Thnankilappu, Kopay, Puthur, Sarasalai, Anthanathidal, Kapputhu, Thondaimanaru, Vallai, Mulli, Nagar Kovil, Mamunai, and Chundikkulam National Park), Mullaitivu (including Chalei, Nanthikadal, Nayaru, and Kokilai lagoons), and Mannar (including Giant's Tank Sanctuary, Vankalai Sanctuary, Erukkulampiddy, Thalaimannar, and Vidaththaltivu). 

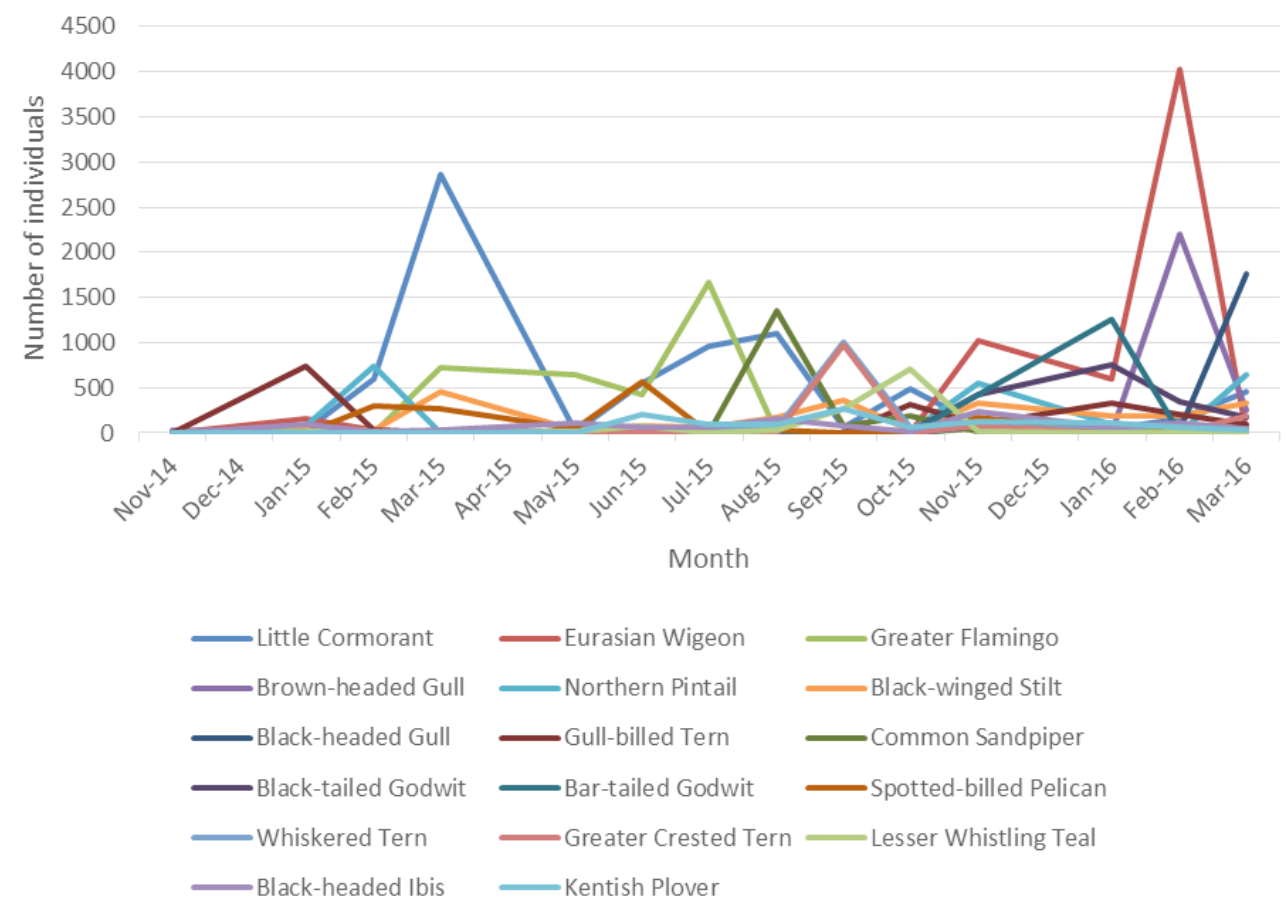

Figure 5: Systematic survey 2014-2016. Monthly variations in the abundance of the most common waterbird species in the present study area.

recorded during the present study (Table 2). The breeding of three of them, the Sooty Tern (Onychoprion fuscatus), Brown Noddy (Anous stolidus) and Lesser Noddy (Anous tenuirostris), was discovered for the first time, in each case on the islet chain Adam's Bridge, Mannar.

The Spot-billed Duck (Anas poeciloryncha), a very rare migrant to Sri Lanka until recently, was observed to have established a breeding population in Jaffna, also a new locality. Others of the eight species include the Indian Courser (Cursorius coromandelicus) and Crab Plover (Dromas ardeola), of whom only very small populations are known in Sri Lanka, the former species only in this region. Of these species again, the Spot-billed Duck, Indian Courser, and Saunders's Tern (Sterna saundersi) are considered Critically Endangered in Sri Lanka (Weerakoon and Gunawardena, 2012).

The Common Coot (Fulica atra), earlier recorded as a very rare breeding resident in Sri Lanka, was found to be common, with nearly or over 1,000 birds at some sites. The Black-necked Stork (Ephippiorhynchus asiaticus), one of the rarest resident bird species, and Critically Endangered in Sri Lanka (Weerakoon and Gunawardena, 2012), was recorded in the region after several decades.

The Greater Flamingo (Phoenicopterus roseus), uncommon elsewhere in Sri Lanka, was recorded in high numbers in the region, for example a flock of approximately 6,000 in the Jaffna Lagoon. During the systematic survey it was observed throughout the year 2015 and in the early part of 2016. It showed the second highest abundance of any migrant bird species in the Jaffna Peninsula during the systematic survey (Wijesundara et al., 2016). The Lesser Flamingo (Phoenicopterus minor) was recorded in Sri Lanka for the first time.

The Glossy Ibis (Plegadis falcinellus) and Comb Duck (Sarkidiornis melanotos), extirpated breeding residents, were recorded as migrants, in their largest numbers to date.
Table 2: Waterbird species which breed in Sri Lanka only in the Jaffna-Mannar area that were recorded during the present study period (2011-2017). See text for important sites. (U=Uncommon; $\mathrm{R}=$ Rare; see Appendix 1 for explanation.)

\begin{tabular}{lc}
\hline Species & Status \\
\hline Spot-billed Duck (Anas poecilorhyncha) & $\mathrm{U}$ \\
Crab Plover (Dromas ardeola) & $\mathrm{R}$ \\
Indian Courser (Cursorius coromandelicus) & $\mathrm{R}$ \\
Saunders's Tern (Sternula saundersi) & $\mathrm{R}$ \\
Bridled Tern (Onychoprion anaethetus) & $\mathrm{U}$ \\
Sooty Tern (Onychoprion fuscatus) & $\mathrm{U}$ \\
Brown Noddy (Anous stolidus) & $\mathrm{U}$ \\
Lesser Noddy (Anous tenuirostris) & $\mathrm{U}$ \\
\hline
\end{tabular}

Avifaunal diversity of selected locations was compared using formal diversity indices such as Shannon Index (Table 3). The island of Mandaitivu, Thondaimanaru, and Vallai had higher Shannon index values in terms of waterbird diversity. Furthermore, these also had higher

Table 3: Systematic survey 2014-2016. Shannon Diversity Index and Shannon Evenness Index for waterbird fauna in selected localities in the northern avifaunal region (sorted by Shannon Index, highest to lowest).

\begin{tabular}{lll}
\hline Locality & $\begin{array}{l}\text { Shannon } \\
\text { Index }\end{array}$ & $\begin{array}{l}\text { Shannon } \\
\text { Evenness }\end{array}$ \\
\hline Mandaitivu & 2.482 & 0.716 \\
Thondaimanaru & 2.184 & 0.601 \\
Vallai & 2.025 & 0.481 \\
Mankumban & 1.252 & 0.433 \\
Allaipiddy & 0.971 & 0.324 \\
\hline
\end{tabular}


evenness values.

\section{DISCUSSION}

\section{Importance of the region for waterbirds}

The study region includes two of the four richest waterbird regions in Sri Lanka: Jaffna (the Peninsula, Chundikkulam National Park to its south, and the islands to its west) and Mannar (from Iluppaikadavai in the north to Adam's Bridge to Silavaturai in the south and extending inland to Giant's Tank Sanctuary).

As stated above, during the period of the study 116 species of waterbirds in 23 families were recorded in the region. In 2010 at least a million shorebirds were seen at the Vidathtalthivu lagoon in the Mannar region, and it has been suggested as possibly the most important shorebird site in the Central Asian Flyway (Sirivardana and Hettige 2010, Warakagoda et al., 2012).

During the period of the study 100,000 or more birds were recorded at a site on four occasions. At the Vankalai Sanctuary, Mannar in 2011 more than 200,000 ducks were seen, in 2014 an estimated 200,000-250,000 ducks, and in 2016 an estimated 500,000 shorebirds (Ceylon Bird Club 2011-2017). On the shores of Jaffna Lagoon and the east coast of Kayts Island 100,000 gulls and terns were recorded in 2014. At gatherings of this scale, in general, the larger the number of birds the greater the species diversity, and the higher the chance of observers missing species present within it in smaller numbers, including rarities.

The reason why this region is so rich in waterbirds may be because it lies at an end point of the major Central Asian flyway (Figure 6). Each year 100,000s of waterbirds migrating away from the Northern winter along this flyway end their journey in Sri Lanka, and most make landfall in Jaffna or Mannar. Furthermore, most of these birds stay on in these areas.

Shorebirds, ducks, gulls, and terns in very large numbers feed and rest in, and fly among, the many wetlands within the Jaffna and Mannar regions, and intermittently fly between these two regions, throughout each migratory season. Waterbirds prefer sites less altered by humans, an exception being salterns, and with low human disturbance. The coastal systems preferred include lagoons, marshes, estuaries, mangroves, sea shore, islets in the sea, sand and mud flats, and salterns. Most birds in these habitats belong to the families Anatidae, Charadriidae, Scolopacidae, Laridae and Sternidae. Locally numerous at these sites are species in Ardeidae, Ciconiidae, Threskiornithidae and Phoenicopteridae. Most of the coastal waterbird species, including all the forms (ducks, waders, gulls, etc.) found in large numbers, are migrants.

Inland systems most preferred by waterbirds include paddy fields, marshes, reservoirs and their associated wetlands. In these habitats, large populations of species in families Phalacrocoracidae and Ardeidae can be seen. Locally common are species in Anatidae, Rallidae and Ciconiidae. These are mostly residents.

In the present study area numerous lagoons, very extensive sand and mud flats bordering these, and low gradients of the littoral region in several localities, form prime feeding sites for waterbirds, especially ducks and shorebirds. The low gradients of the littoral region (for example at the Mannar causeway) also enables flamingos to stand in the sea more than $1 \mathrm{~km}$ away from the shore. Numerous sites of all the other wetland types described above occur in the region.

The total extent of mangroves in the present study areas is over 3,400 ha or about $29 \%$ of the total extent of mangroves in Sri Lanka (MOE 2012, Rajkumar and Wijesundara, 2016). The largest extents of the mangroves in Sri Lanka are recorded from the north, northwest, and eastern coasts (Pinto, 1986, Wetlands International 2010, Prasanna and Ranawana, 2014). These areas support large numbers of prey species of waterbirds (e.g. fish, mollusks, other invertebrates, and plankton). The phytoplankton contributes to a major portion of the primary production in

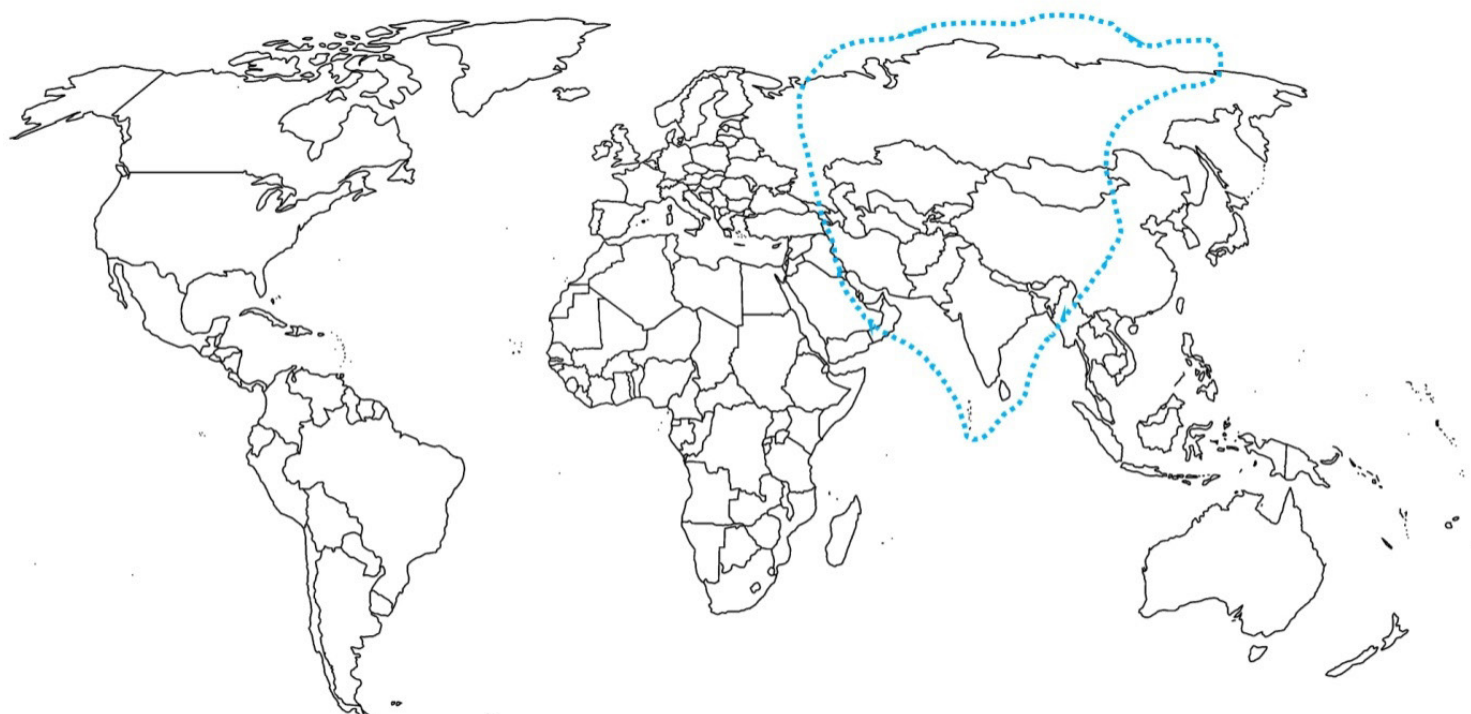

Central Asian Flyway

Figure 6 Central Asian Flyway. After Wetlands International (2012). Map prepared by Saumya Wanniarachchi. 
these lagoons. This provides the basis for the food chain. High densities of prey species support large populations of waterbird species. The study region also has some of the most seriously threatened wetlands in Asia (Scott, 1989).

The great majority of these wetlands are either not or marginally utilized by humans, and most of the adjacent human populations are sparse, with little disturbance from them. Ironically, the armed conflict in the country, which in fact was concentrated in this region, protected birds at wetlands within it. Civilian firearms were banned by both parties, upon which the hunting of waterbirds ceased; but with peace this has resumed. During the conflict it had been observed that the sound of artillery made waterbirds leave certain wetlands in this region but that they returned soon when the spell of disturbance was over.

\section{Diversity of waterbirds in the region}

The species of waterbirds resident in Sri Lanka which breed only in the region are listed in Table 2. Of these, Sooty Tern, Brown Noddy, Lesser Noddy, and Saunders's Tern, are known to breed only on Adam's Bridge.

The Spot-billed Duck was a very rare migrant to Sri Lanka until recently (Henry, 1998). In 2003 it was established as a breeding resident in Mannar (Warakagoda and Sirivardana, 2006), and in 2011 in Jaffna (Ceylon Bird Club 2011-2017). The species has now established breeding populations in both the Mannar and Jaffna regions (Ibid.) Adults with young were observed also during the systematic survey, in Jaffna.

The Indian Courser is a very rare breeding resident species in Sri Lanka, and it is confined to the present region. It was recorded in Jaffna after more than a decade, on Delft Island, during the systematic survey (2014 - 2016).

The Crab Plover is a rare and local breeding resident in Sri Lanka seen at the Adam's Bridge islets, northwestern coastal areas, and very seldom elsewhere. It was observed in these localities in this study with no other records in Sri Lanka during this period. The species breeds in the present region (Jaffna-Mannar), as young have been recorded, and observed to be fed, on Mannar Island (Gunawardena, 2007). All indications are that the breeding site is Adam's Bridge, but a nest is yet to be found there. This monotypic species has been recorded as nesting only around the Arabian Peninsula globally to date (BirdLife International 2017).

Of other species, the Common Coot had been earlier recorded as a very rare breeding resident in Sri Lanka (Henry, 1971). It has now been recorded with over 1,000 individuals in some sites such as the Giant's Tank in Mannar, during the present and other recent studies (Wijeyamohan et al., 2002). This species appears to have spread gradually eastwards to Vavuniya, where it has been observed in one of the large tanks in the city, and northwards to Jaffna, where it occurs in considerable numbers. It was also observed in large numbers during the systematic survey in some areas in Jaffna such as Vallai.

The Black-necked Stork has probably the smallest population size of any resident bird species in Sri Lanka. It was recorded in the eastern coastal strip, in the Nilaveli area, during the present study. This is the only record of it outside the south-east of Sri Lanka for several decades.
Greater Flamingos were seen in the 1,000s during the migrant seasons in this study. They were observed yearround in the Jaffna region during the systematic survey (2014 - 2016). This indicates that they stay on in Sri Lanka beyond the migrant season in some years, as previous workers (e.g. Legge, 1880, Henry, 1971) have suggested. It appears that more or less regularly for decades now about 10,000 flamingos have been gathering in the Chundikkulam Lagoon around May. For some decades the species has been known to remain in Sri Lanka outside the migrant season. This was mostly in the South East, represented by a few 100 to $>1,000$ birds. Their nearest known breeding site is the Rann of Kutch at the India-Pakistan border. It was noted that in such years (when they stayed in Sri Lanka) the conditions at the Rann were unfavorable for breeding. The causal connection between this fact and not migrating is not known. One of the earliest records of this species staying on in Sri Lanka beyond the migrant season is from Legge (1880). He gives a record of a large flock of flamingos seen in Jaffna during June. Wait (1925) also records seeing a large flock in June in Kokkilai Lagoon. In Henry (1998) it is reported that a considerable number of flamingos loiter through the south-western monsoon (May-September), and the building of nest mounds has occasionally been observed. To date there is no definite indication of the species breeding in Sri Lanka. During the systematic survey, greater flamingos have been observed in large numbers $($ i.e. $>1,000)$ in June and July in the Jaffna Peninsula.

The Lesser Flamingo was recorded in Sri Lanka for the first time, with two individuals observed in a flock of about 200 Greater Flamingo, in 2013, in Jaffna. The next nearest record of its occurrence is Andhra Pradesh, India.

Two species which were once breeding residents and became extinct as breeding residents a century ago later reappeared as migrants in Sri Lanka, viz. the Glossy Ibis and the Comb Duck (Henry, 1998). At present, their largest numbers are recorded in the Jaffna and Mannar areas. The largest flocks of Glossy Ibis and Comb Duck in Sri Lanka were recorded in Jaffna during the present study period. Over 200 individuals of the Glossy Ibis have been recorded by the Ceylon Bird Club during the present study period, and 100+ individuals in the systematic survey (2014-2016) from Sarasalai, Jaffna.

Two migrant species, the Wigeon (Anas penelope) and Black-tailed Godwit (Limosa limosa) were very rarely recorded in Sri Lanka until a few decades ago (Legge, 1880, Wait, 1925, Henry, 1971). Since then, during most seasons they have been recorded in the $1,000 \mathrm{~s}$, the Wigeon only in the Jaffna and Mannar regions (Henry, 1998). For example, in February 2016 over 4,000 Wigeon were recorded from Mankumban, Jaffna during the systematic survey. Black-tailed Godwits were also recorded in large numbers in Jaffna, with flocks of several 1,000 individuals.

The diversity indices suggest that among the selected areas in Jaffna, the island of Mandaitivu, Thondaimanaru, and Vallai had higher waterbird diversity. Furthermore, these also had higher evenness values. This suggests that in these areas the bird species were more or less equally abundant or evenly distributed. 


\section{Conservation}

Recently several areas that include major waterbird habitats have been either declared or proposed as protected areas within the present study area (see Figure 7). These include two newly declared national parks, i.e. Adams Bridge and Delft Island National Parks, and two sanctuaries upgraded to National Park status in 2015, i.e. Chundikulam National Park and Madu Road National Park (Government of Sri Lanka Gazette No 1920/3 2015). Furthermore, it is proposed to upgrade Kokilai Sanctuary as a National Park including the adjacent Nayaru Lagoon area (Mallawatantri et al., 2014). This area also includes highly significant waterbird habitats.

The entire Jaffna Lagoon and the area covering Karaveddi-Nagarkovil region in the Jaffna Peninsula have been either proposed or declared as sanctuaries/ nature reserves. These include most of the significant waterbird habitats in the Jaffna Peninsula. For example, Sarasalai, Anthanathidal, Vallai, and Thondaimanaru areas in this proposed sanctuary include major waterbird habitats providing refuge for significant species such as the Greater Flamingo, Glossy Ibis, and Common Coot. Some of these areas (e.g. Nagar Kovil) also include significant extents of mangroves. Nagar Kovil has recently (in 2016) been declared as a nature reserve (Department of Wildlife Conservation Sri Lanka 2017).

The entire coastal and pelagic strip north from Iluppaikadavai south to Toddaveli (on Mannar Island) has been very recently (in 2016) declared as a Nature Reserve, the Vidaththaltivu Nature Reserve (Department of Wildlife Conservation Sri Lanka 2017). This area is used by very large numbers of migrant birds each year. For example, over a million migrant birds were recorded in Vidaththaltivu in 2010 (Sirivardana and Hettige, 2010, Warakagoda et al., 2012). Mannar area also includes a Ramsar Wetland, the Vankalai Sanctuary (Ramsar Convention, 2013). All of these areas on the northwestern coastal area of Sri Lanka are important for the survival of avian species which are specialties in the northern region, such as Crab Plover and Indian Courser. Furthermore, Nanthikadal Lagoon has been proposed as a sanctuary and re-establishment of Vavunikulum Sanctuary is also proposed (Mallawatantri et al. 2014). Both these areas are significant as habitats for both resident and migrant waterbirds. For example, the systemitic survey recorded 100+ individuals of Eurasian Spoonbills (Platalea leucorodia) in one flock and several Glossy Ibis in Nanthikadal Lagoon in 2015.

The present study area (especially Jaffna, Mullaitivu, and Mannar) has large extents of prime waterbird habitats such as mangroves and salt pans. Road and hotel construction have negatively impacted on these habitats. Destruction of mangroves, especially during post-war years, is evident in many areas such as Mandaitivu. The ongoing salt water exclusion scheme in the Thondaimanaru lagoon results in the slow desalination of the lagoon. It will have far-reaching ecological consequences including threats to the mangrove ecosystems of the area and the associated bird life.

\section{CONCLUSION}

The present study area has a number of important sites for waterbird conservation. It includes two of the four richest waterbird regions in Sri Lanka, namely Jaffna region (including islands and the Chundikkulam National Park) and Mannar region (including Adam's Bridge National Park and Giant's Tank Sanctuary). The study recorded a total of 116 species of waterbirds in 23 families in the northern avifaunal region. These included eight species which breed only within the region, and three of them were recorded as breeding in Sri Lanka for the first time, all on Adam's Bridge. The present study area also supports a large number of Greater Flamingo (Phoenicopterus roseus), which is now uncommon elsewhere in Sri Lanka.

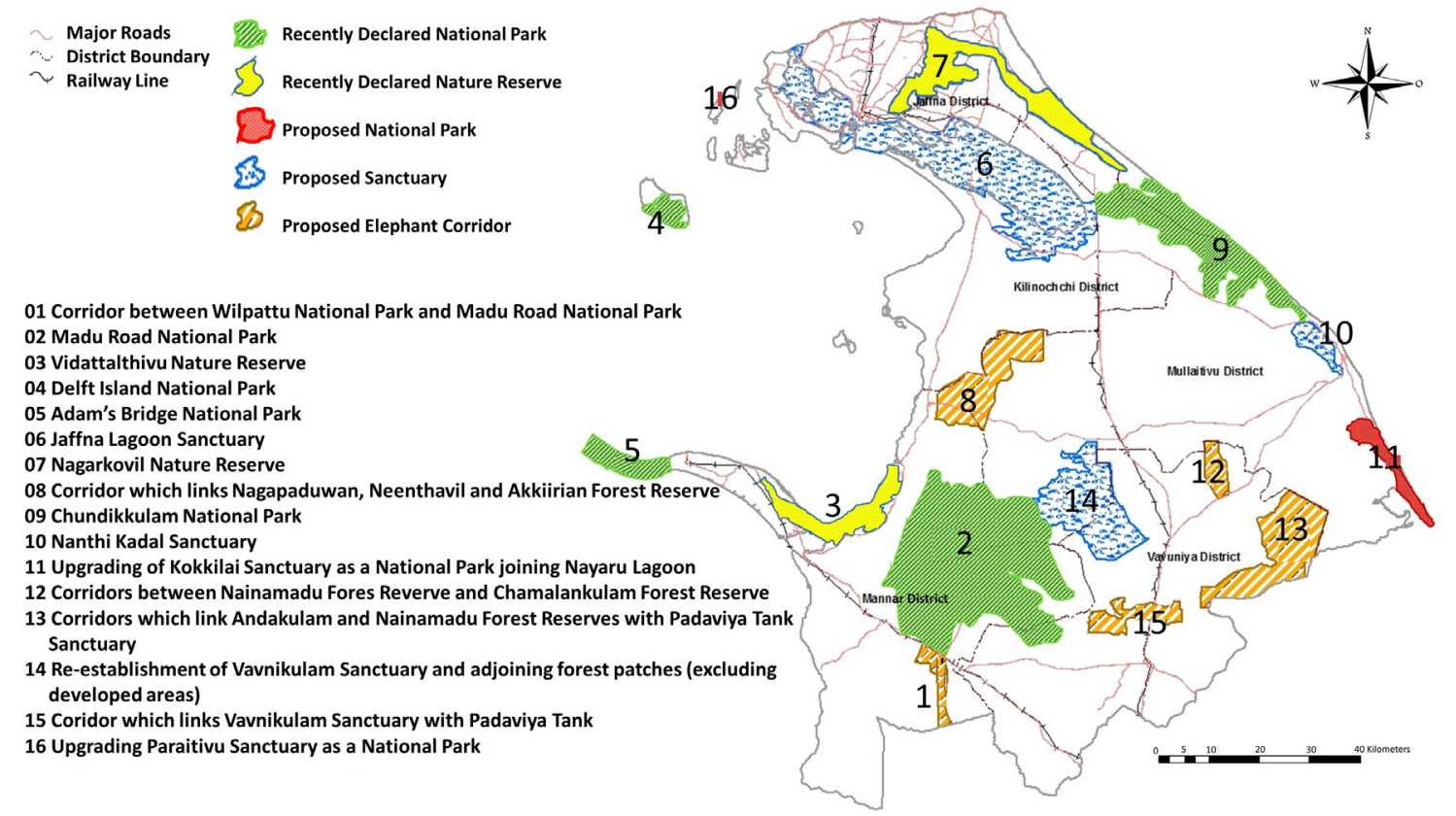

Figure 7: Proposed and recently declared wildlife conservation areas in the northern region of Sri Lanka. The systematic survey was based on sites 2, 3, 4, 6, 7, 9, 10,11, and 16; the censuses of the Ceylon Bird Club were based also on the other sites shown in addition to these sites. After Department of Wildlife Conservation, Sri Lanka, 2011; Map prepared by Saumya Wanniarachchi. 
Furthermore, it is one of very few global breeding areas of the Crab Plover (Dromas ardeola), which is a monotypic species.

\section{ACKNOWLEDGEMENTS}

The systematic survey (October 2014 - March 2016) was partially funded by a research grant from the University of Peradeniya (RG/2014/41/S) to Chaminda S. Wijesundara. Some of the field equipment were provided by the Department of Zoology, University of Peradeniya. We also thank the Ceylon Bird Club members who participated in the annual surveys during the period reported in this study.

\section{REFERENCES}

Bibby, C. J., Burgess, N.D., Hill, D. A. and Mustoe, S.H. (2000). Bird Census Techniques. $2^{\text {nd }}$ edition. Academic Press, London. 277 pp.

BirdLife International. (2017). Species factsheet: Dromas ardeola. Available from: http://www.birdlife.org Accessed on: July 15, 2017.

Buckland, S. T., Anderson, D. R., Burnham, K. P., Laake, J. L., Borchers, D. L. and Thomas, L. (2001). Introduction to Distance Sampling: Estimating Abundance of Biological Populations. Oxford University Press, Oxford.

Ceylon Bird Club. (2011-2017). Ceylon Bird Club Notes.

Clements, J. F., Schulenberg, T. S., Iliff, M. J., Roberson, D., Fredericks, T. A., Sullivan, B. L. and Wood, C. L. (2016). The eBird/Clements checklist of birds of the world: v2016. http://www.birds.cornell.edu/ clementschecklist/download/.

Department of Wildlife Conservation Sri Lanka. (2017). Nature Reserves. http://www.dwc.gov.lk/index.php/en/ nature-reserves.

Government of Sri Lanka Gazette No.1920/3. (2015). The Gazette of the Democratic Socialist Republic of Sri Lanka Extraordinary No. 1920/3. Colombo. Pp. 1A-10A.

Gunawardena, K. (2007). Ceylon Bird Club Notes 35.

Henry, G. M. (1971). A Guide to the Birds of Ceylon. $2^{\text {nd }}$ edition. Oxford University Press, London.

Henry, G. M. (1998). A Guide to the Birds of Sri Lanka. $3^{\text {rd }}$ edition. K.V.G. de Silva and Sons, Kandy.

Legge, W. V. (1880). A History of the Birds of Ceylon-2 Vols. Published by the Author, London.

Mallawatantri, Marambe, A. B. and Skehan, C. (2014). Integrated Strategic Environment Assessment of the Northern Province of Sri Lanka. Central Environmental Authority and Disaster Management Centre, Colombo Sri Lanka.

Marsden, S. J. (1999). Estimation of parrot and hornbill densities using a point count distance sampling method. Ibis 141: 377-390.

Ministry of Environment (2012). The National Red List 2012 of Sri Lanka; Conservation Status of the Fauna and Flora. Ministry of Environment, Colombo, Sri Lanka. viii +476 pp.

Pinto, L. (1986). Mangroves of Sri Lanka. Natural Resources, Energy \& Science Authority of Sri Lanka, Colombo. Sri Lanka. 54 pp.
Prasanna, M. G. M., and Ranawana, K. B. (2014). Guide to Mangroves of Sri Lanka. Biodiversity Secretariat, Ministry of Environment and Renewble Energy, Battaramulla, Sri Lanka. 54 pp.

Price, T. D., Hooper,D. M. , Buchanan, C. D., Johansson, U. S., Tietze, D. T., Alström, P., Olsson, U., GhoshHarihar, M., Ishtiaq, F. and Gupta, S. K. (2014). Niche filling slows the diversification of Himalayan songbirds. Nature 509: 222-225.

Rajkumar, P., and Wijesundara, C. S. (2016). Distribution of mangrove species on the islands of Jaffna Peninsula, Sri Lanka. In: Proceedings of the International Forestry and Environment Symposium 2016. University of Sri Jayawardenepura, Sri Lanka, Page 14.

Raman, T. R. S. (2003). Assessment of census techniques for interspecific comparisons of tropical rainforest bird densities: a field evaluation in the Western Ghats, India. Ibis 145: 9-21.

Ramsar Convention. (2013). The Annotated Ramsar List Sri Lanka. Available from: http://ramsar.rgis.ch/cda/en/ ramsar-documents-list-ano-srilanka/main/ramsar/1-31218\%5E16173_4000_0d. Accessed on: July 15, 2017.

Rasmussen, P. C., and Anderton, J. (2012). Birds of South Asia: The Ripley Guide. 2 vols. Second edition. Smithsonian Institution, Washington, D.C., USA, and Lynx Edicions, Barcelona, Spain. 684 pp.

Scott, D. A. (1980). A Preliminary Inventory of Wetlands of International Importance for Waterfowl in West Europe and North-west Africa. IWRB Special Publication No. 2. International Waterfowl and Wetlands Research Bureau, Slimbridge, UK.

Scott, D. A. (1989). A Directory of Asian Wetlands. IUCN, Gland. 1181 pp.

Sirivardana, U., and Hettige, U. (2010). A million shorebirds at Vidattaltivu. Ceylon Bird Club Notes: 52-53.

Sutherland, W. J. (2006). Ecological Census Techniques: A Handbook. 2nd edition. Cambridge University Press, Cambridge.

Wait, W. E. (1925). Manual of the Birds of Ceylon. Dulau \& Co., Ltd., London.

Warakagoda, D., Inskipp, C., Inskipp, T. and Grimmett, R. (2012). Birds of Sri Lanka-Helm Field Guide. Christopher Helm, London.

Warakagoda, D., and Sirivardana, U. (2006). Status of waterfowl in Sri Lanka. In: C. Bambaradeniya, (Ed.). The Fauna of Sri Lanka. The World Conservation Union (IUCN), Colombo. Pp. 204-215.

Warakagoda, D., and Sirivardana, U. (2009). The avifauna of Sri Lanka: An overview of the current status. Taprobanica 01: 28-35.

Weerakoon, D., and Gunawardena, K. (2012). The taxonomy and conservation status of birds in Sri Lanka. In: D. K. Weerakoon and S. Wijesundara, (Eds.). The National Red List 2012 of Sri Lanka: Conservation Status of the Flora and Fauna. Ministry of Environment, Colombo. Pp. 114-133.

Wei, D. L. Z., Bloem, A., Delany, S., Martakis, G. and Quintero, J. O. (2009). Status of Water Birds in Asia: Results of the Asian Water Bird Census: 1987-2007. Wetlands International, Kuala Lumpur.

Wetlands International. (2010). Guidance on waterbird 
monitoring methodology: Field Protocol for waterbird counting. Wetlands International, Wageningen, The Netherlands.

Wetlands International. (2012). Waterbird Population Estimates, Fifth Edition. Summary Report. Wetlands International, Wageningen, The Netherlands.

Wijesundara, C. S., Chathuranga, D., Hettiarachchi, T., Perera, N., Wanniarachchi S., and Weerakoon, G. (2016). Population size of the Greater Flamingo in the Jaffna Peninsula, Sri Lanka. In: Proceedings of the
Postgraduate Institute of Science Research Congress 2016. Postgraduate Institute of Science, University of Peradeniya, Page 80.

Wijeyamohan, S., Baheerathi, T., Luxmy, S., Prabha, K., Sajithran, T. M., Sivagini, S., Sivagnanam, V., Theeban, S., Wijesundara, C. and Santiapillai, C. (2002). Diversity of Birds in the Giant's Tank, Wanni Region, Sri Lanka. Tigerpaper 29: 11-14.

\section{Appendix 1: Status of waterbirds found in the northern avifaunal region of Sri Lanka.}

Information based on the data from Ceylon Bird Club (2011-2017) and the systematic survey (2014-2016).

Status:

R - Resident, M - Migrant

M, R denotes the main populations being migrant, with minor resident populations.

$\mathrm{R}, \mathrm{M}$ denotes the main populations being resident, with minor migrant populations.

Distribution Zones:

C - Coastal, I - Inland

$\mathrm{C}$, I denotes the main populations being coastal, with minor inland populations.

I, C denotes the main populations being inland, with minor coastal populations.

Abundance:

C - Common (found in fair numbers within its zone/s / main zone)

L - Locally common (occurs in fair numbers locally but is rare or not well distributed elsewhere)

U - Uncommon (found in small numbers throughout its zone /s or locally)

$\mathrm{R}$ - Rare (occurs only in very small numbers or only occasionally).

\begin{tabular}{|c|c|c|c|}
\hline Family \& Species & Resident/Migrant & Zone & Abundance \\
\hline \multicolumn{4}{|l|}{ Family Podicipedidae } \\
\hline Little Grebe Tachybaptus ruficollis & $\mathrm{R}$ & $\mathrm{I}, \mathrm{C}$ & $\mathrm{L}$ \\
\hline \multicolumn{4}{|l|}{ Family Phalacrocoracidae } \\
\hline Little Cormorant Phalacrocorax niger & $\mathrm{R}$ & $\mathrm{I}, \mathrm{C}$ & $\mathrm{C}$ \\
\hline Indian Shag Phalacrocorax fuscicollis & $\mathrm{R}$ & $\mathrm{I}, \mathrm{C}$ & $\mathrm{C}$ \\
\hline Great Cormorant Phalacrocorax carbo & $\mathrm{R}$ & I & $\mathrm{U}$ \\
\hline \multicolumn{4}{|l|}{ Family Anhingidae } \\
\hline Indian Darter Anhinga melanogaster & $\mathrm{R}$ & $\mathrm{C}, \mathrm{I}$ & $\mathrm{U}$ \\
\hline \multicolumn{4}{|l|}{ Family Pelecanidae } \\
\hline Spotted-billed Pelican Pelecanus philippensis & $\mathrm{R}$ & $\mathrm{C}, \mathrm{I}$ & $\mathrm{L}$ \\
\hline \multicolumn{4}{|l|}{ Family Ardeidae } \\
\hline Yellow Bittern Ixobrychus sinensis & $\mathrm{R}, \mathrm{M}$ & $\mathrm{I}, \mathrm{C}$ & $\mathrm{C}$ \\
\hline Black Bittern Ixobrychus flavicollis & $\mathrm{R}, \mathrm{M}$ & $\mathrm{I}, \mathrm{C}$ & $\mathrm{U}$ \\
\hline Night Heron Nycticorax nycticorax & $\mathrm{R}$ & $\mathrm{I}, \mathrm{C}$ & $\mathrm{L}$ \\
\hline Little Green Heron Butorides striatus & $\mathrm{R}$ & $\mathrm{I}, \mathrm{C}$ & $\mathrm{L}$ \\
\hline Indian Pond Heron Ardeola grayii & $\mathrm{R}$ & $\mathrm{C}, \mathrm{I}$ & $\mathrm{C}$ \\
\hline Median Egret Ardea intermedia & $\mathrm{R}$ & $\mathrm{C}, \mathrm{I}$ & $\mathrm{C}$ \\
\hline Cattle Egret Ardea ibis & $\mathrm{R}, \mathrm{M}$ ? & $\mathrm{I}, \mathrm{C}$ & $\mathrm{C}$ \\
\hline Grey Heron Ardea cinerea & $\mathrm{R}$ & $\mathrm{C}, \mathrm{I}$ & $\mathrm{C}$ \\
\hline Purple Heron Ardea purpurea & $\mathrm{R}$ & $\mathrm{I}, \mathrm{C}$ & $\mathrm{C}$ \\
\hline Large Egret Egretta alba & $\mathrm{R}$ & $\mathrm{C}, \mathrm{I}$ & $\mathrm{C}$ \\
\hline Little Egret Egretta garzetta & $\mathrm{R}$ & $\mathrm{C}, \mathrm{I}$ & $\mathrm{C}$ \\
\hline Indian Reef Heron Egretta gularis & M & $\mathrm{C}$ & $\mathrm{R}$ \\
\hline \multicolumn{4}{|l|}{ Family Ciconiidae } \\
\hline Painted Stork Mycteria leucocephala & $\mathrm{R}$ & $\mathrm{C}, \mathrm{I}$ & $\mathrm{L}$ \\
\hline
\end{tabular}




\begin{tabular}{|c|c|c|c|}
\hline Family \& Species & Resident/Migrant & Zone & Abundance \\
\hline Openbill Anastomus oscitans & $\mathrm{R}$ & $\mathrm{I}, \mathrm{C}$ & $\mathrm{C}$ \\
\hline White-necked Stork Ciconia episcopus & $\mathrm{R}$ & $\mathrm{I}, \mathrm{C}$ & $\mathrm{U}$ \\
\hline Black-necked Stork Ephippiorhynchus asiaticus & $\mathrm{R}$ & $\mathrm{C}$ & $\mathrm{R}$ \\
\hline \multicolumn{4}{|l|}{ Family Threskiornithidae } \\
\hline Glossy Ibis Plegadis falcinellus & M & $\mathrm{C}, \mathrm{I}$ & $\mathrm{U}$ \\
\hline White Ibis Threskiornis melanocephalus & $\mathrm{R}$ & $\mathrm{C}, \mathrm{I}$ & $\mathrm{L}$ \\
\hline Spoonbill Platalea leucorodia & $\mathrm{R}$ & $\mathrm{C}, \mathrm{I}$ & $\mathrm{L}$ \\
\hline \multicolumn{4}{|l|}{ Family Phoenicopteridae } \\
\hline Greater Flamingo Phoenicopterus ruber & M & $\mathrm{C}$ & $\mathrm{L}$ \\
\hline Lesser Flamingo Phoeniconaias minor & M & $\mathrm{C}$ & $\mathrm{R}$ \\
\hline \multicolumn{4}{|l|}{ Family Anatidae } \\
\hline Lesser Whistling Teal Dendrocygna javanica & $\mathrm{R}$ & $\mathrm{I}, \mathrm{C}$ & $\mathrm{C}$ \\
\hline Ruddy Shelduck Tadorna ferrugineaI & M & $\mathrm{C}$ & $\mathrm{R}$ \\
\hline Comb Duck Sarkidiornis melanotos & $\mathrm{M}, \mathrm{R}$ ? & I & $\mathrm{U}$ \\
\hline Cotton Teal Nettapus coromandelianus & $\mathrm{R}$ & I & $\mathrm{U}$ \\
\hline Wigeon Anas penelope & M & $\mathrm{C}$ & $\mathrm{C}$ \\
\hline Common Teal Anas crecca & M & $\mathrm{C}$ & $\mathrm{U}$ \\
\hline Spot-billed Duck Anas poecilorhyncha & $\mathrm{R}, \mathrm{M}$ ? & $\mathrm{C}, \mathrm{I}$ & $\mathrm{U}$ \\
\hline Pintail Anas acuta & M & $\mathrm{C}, \mathrm{I}$ & $\mathrm{C}$ \\
\hline Garganey Anas querquedula & M & $\mathrm{C}, \mathrm{I}$ & $\mathrm{C}$ \\
\hline Shoveller Anas clypeata & M & $\mathrm{C}, \mathrm{I}$ & $\mathrm{L}$ \\
\hline \multicolumn{4}{|l|}{ Family Rallidae } \\
\hline Ruddy Crake Porzana fusca & $\mathrm{R}$ & $\mathrm{I}, \mathrm{C}$ & $\mathrm{U}$ \\
\hline White-breasted Waterhen Amaurornis phoenicurus & $\mathrm{R}$ & $\mathrm{I}, \mathrm{C}$ & $\mathrm{C}$ \\
\hline Common Moorhen Gallinula chloropus & $\mathrm{R}$ & $\mathrm{I}, \mathrm{C}$ & $\mathrm{U}$ \\
\hline Purple Coot Porphyrio porphyrio & $\mathrm{R}$ & $\mathrm{I}, \mathrm{C}$ & $\mathrm{C}$ \\
\hline Watercock Gallicrex cinerea & $\mathrm{R}$ & $\mathrm{I}, \mathrm{C}$ & $\mathrm{U}$ \\
\hline Common Coot Fulica atra & $\mathrm{R}$ & $\mathrm{I}, \mathrm{C}$ & $\mathrm{L}$ \\
\hline \multicolumn{4}{|l|}{ Family Jacanidae } \\
\hline Pheasant-tailed Jacana Hydrophasianus chirurgus & $\mathrm{R}$ & $\mathrm{I}, \mathrm{C}$ & $\mathrm{C}$ \\
\hline \multicolumn{4}{|l|}{ Family Rostratulidae } \\
\hline Painted Snipe Rostratula benghalensis & $\mathrm{R}$ & $\mathrm{I}, \mathrm{C}$ & $\mathrm{U}$ \\
\hline \multicolumn{4}{|l|}{ Family Haematopodidae } \\
\hline Oystercatcher Haematopus ostralegus & M & $\mathrm{C}$ & $\mathrm{R}$ \\
\hline \multicolumn{4}{|l|}{ Family Recurvirostridae } \\
\hline Black-winged Stilt Himantopus himantopus & $\mathrm{R}, \mathrm{M}$ & $\mathrm{C}, \mathrm{I}$ & $\mathrm{C}$ \\
\hline Avocet Recurvirostra avosetta & M & $\mathrm{C}$ & $\mathrm{R}$ \\
\hline \multicolumn{4}{|l|}{ Family Dromadidae } \\
\hline Crab Plover Dromas ardeola & $\mathrm{R}$ & $\mathrm{C}$ & $\mathrm{R}$ \\
\hline \multicolumn{4}{|l|}{ Family Burhinidae } \\
\hline Stone-Curlew Burhinus oedicnemus & $\mathrm{R}$ & $\mathrm{C}, \mathrm{I}$ & $\mathrm{U}$ \\
\hline Great Stone-Plover Esacus recurvirostris & $\mathrm{R}$ & $\mathrm{C}, \mathrm{I}$ & $\mathrm{U}$ \\
\hline \multicolumn{4}{|l|}{ Family Glareolidae } \\
\hline Indian Courser Cursorius coromandelicus & $\mathrm{R}$ & $\mathrm{C}$ & $\mathrm{R}$ \\
\hline Collared Pratincole Glareola pratincola & M & $\mathrm{C}$ & $\mathrm{R}$ \\
\hline Oriental Pratincole Glareola maldivarum & $\mathrm{R}$ & $\mathrm{I}, \mathrm{C}$ & $\mathrm{R}$ \\
\hline \multicolumn{4}{|l|}{ Family Charadriidae } \\
\hline Little Ringed Plover Charadrius dubius & $\mathrm{R}, \mathrm{M}$ & $\mathrm{C}, \mathrm{I}$ & $\mathrm{U}$ \\
\hline Ringed Plover Charadrius hiaticula & M & $\mathrm{C}, \mathrm{I}$ & $\mathrm{R}$ \\
\hline Kentish Plover Charadrius alexandrinus & $\mathrm{R}, \mathrm{M}$ & $\mathrm{C}, \mathrm{I}$ & $\mathrm{L}$ \\
\hline
\end{tabular}




\begin{tabular}{|c|c|c|c|}
\hline Family \& Species & Resident/Migrant & Zone & Abundance \\
\hline Lesser Sand Plover Charadrius mongolus & $\mathrm{M}$ & $\mathrm{C}, \mathrm{I}$ & $\mathrm{C}$ \\
\hline Large Sand Plover Charadrius leschenaultii & M & $\mathrm{C}$ & $\mathrm{U}$ \\
\hline Asiatic Golden Plover Pluvialis fulva & M & $\mathrm{C}, \mathrm{I}$ & $\mathrm{L}$ \\
\hline Grey Plover Pluvialis squatarola & M & $\mathrm{C}$ & $\mathrm{U}$ \\
\hline Yellow-wattled Lapwing Vanellus malabaricus & $\mathrm{R}$ & $\mathrm{C}, \mathrm{I}$ & $\mathrm{U}$ \\
\hline Red-wattled Lapwing Vanellus indicus & $\mathrm{R}$ & $\mathrm{I}, \mathrm{C}$ & $\mathrm{U}$ \\
\hline \multicolumn{4}{|l|}{ Family Scolopacidae } \\
\hline Great Knot Calidris tenuirostris & M & $\mathrm{C}$ & $\mathrm{R}$ \\
\hline Red Knot Calidris canutus & M & $\mathrm{C}$ & $\mathrm{R}$ \\
\hline Sanderling Calidris alba & M & $\mathrm{C}$ & $\mathrm{U}$ \\
\hline Little Stint Calidris minuta & M & $\mathrm{C}, \mathrm{I}$ & $\mathrm{C}$ \\
\hline Temminck's Stint Calidris temminckii & M & $\mathrm{C}, \mathrm{I}$ & $\mathrm{R}$ \\
\hline Long-toed Stint Calidris subminuta & M & $\mathrm{C}$ & $\mathrm{R}$ \\
\hline Curlew Sandpiper Calidris ferruginea & M & $\mathrm{C}, \mathrm{I}$ & $\mathrm{C}$ \\
\hline Broad-billed Sandpiper Limicola falcinellus & M & $\mathrm{C}$ & $\mathrm{U}$ \\
\hline Ruff Philomachus pugnax & M & $\mathrm{C}$ & $\mathrm{U}$ \\
\hline Pintail Snipe Gallinago stenura & M & $\mathrm{I}, \mathrm{C}$ & $\mathrm{C}$ \\
\hline Black-tailed Godwit Limosa limosa & M & $\mathrm{C}, \mathrm{I}$ & $\mathrm{C}$ \\
\hline Bar-tailed Godwit Limosa lapponica & M & $\mathrm{C}$ & $\mathrm{R}$ \\
\hline Whimbrel Numenius phaeopus & M & $\mathrm{C}$ & $\mathrm{U}$ \\
\hline Eurasian Curlew Numenius arquata & M & $\mathrm{C}$ & $\mathrm{U}$ \\
\hline Common Redshank Tringa totanus & M & $\mathrm{C}, \mathrm{I}$ & $\mathrm{C}$ \\
\hline Marsh Sandpiper Tringa stagnatilis & M & $\mathrm{C}, \mathrm{I}$ & $\mathrm{C}$ \\
\hline Common Greenshank Tringa nebularia & M & $\mathrm{C}, \mathrm{I}$ & $\mathrm{U}$ \\
\hline Green Sandpiper Tringa ochropus & M & $\mathrm{I}, \mathrm{C}$ & $\mathrm{R}$ \\
\hline Wood Sandpiper Tringa glareola & M & $\mathrm{C}, \mathrm{I}$ & $\mathrm{U}$ \\
\hline Terek Sandpiper Xenus cinereus & M & $\mathrm{C}$ & $\mathrm{U}$ \\
\hline Common Sandpiper Actitis hypoleucos & M & $\mathrm{C}, \mathrm{I}$ & $\mathrm{U}$ \\
\hline Turnstone Arenaria interpres & M & $\mathrm{C}$ & $\mathrm{U}$ \\
\hline Red-necked Phalarope Phalaropus lobatus & M & $\mathrm{C}$ & $\mathrm{R}$ \\
\hline \multicolumn{4}{|l|}{ Family Laridae } \\
\hline Great Black-headed Gull Larus ichthyaetus & M & $\mathrm{C}$ & $\mathrm{L}$ \\
\hline Common Black-headed Gull Larus ridibundus & M & $\mathrm{C}$ & $\mathrm{R}$ \\
\hline Brown-headed Gull Larus brunnicephalus & M & $\mathrm{C}$ & $\mathrm{L}$ \\
\hline Slender-billed Gull Larus genei & M & $\mathrm{C}$ & $\mathrm{R}$ \\
\hline Lesser Black-backed Gull Larus fuscus & M & $\mathrm{C}$ & $\mathrm{L}$ \\
\hline \multicolumn{4}{|l|}{ Family Sternidae } \\
\hline Gull-billed Tern Sterna nilotica & $\mathrm{M}, \mathrm{R}$ & $\mathrm{C}, \mathrm{I}$ & $\mathrm{L}$ \\
\hline Caspian Tern Sterna caspia & $\mathrm{R}, \mathrm{M}$ & $\mathrm{C}, \mathrm{I}$ & $\mathrm{L}$ \\
\hline Large Crested Tern Sterna bergii & $\mathrm{R}$ & $\mathrm{C}$ & $\mathrm{L}$ \\
\hline Lesser Crested Tern Sterna bengalensis & M & $\mathrm{C}$ & $\mathrm{L}$ \\
\hline Sandwich Tern Sterna sandvicensis & M & $\mathrm{C}$ & $\mathrm{R}$ \\
\hline Roseate Tern Sterna dougallii & $\mathrm{R}$ & $\mathrm{C}$ & $\mathrm{U}$ \\
\hline Common Tern Sterna hirundo & $\mathrm{M}, \mathrm{R}$ & $\mathrm{C}$ & $\mathrm{L}$ \\
\hline Bridled Tern Sterna anaethetus & $\mathrm{M}, \mathrm{R}$ & $\mathrm{C}$ & $\mathrm{U}$ \\
\hline Little Tern Sterna albifrons & $\mathrm{R}$ & $\mathrm{C}, \mathrm{I}$ & $\mathrm{L}$ \\
\hline Saunders's Tern Sterna saundersi & $\mathrm{R}$ & $\mathrm{C}$ & $\mathrm{R}$ \\
\hline Sooty Tern Sterna fuscata & $\mathrm{M}, \mathrm{R}$ & $\mathrm{C}$ & $\mathrm{U}$ \\
\hline Whiskered Tern Chlidonias hybridus & M & $\mathrm{C}, \mathrm{I}$ & $\mathrm{C}$ \\
\hline White-winged Black Tern Chlidonias leucopterus & M & $\mathrm{C}, \mathrm{I}$ & $\mathrm{L}$ \\
\hline
\end{tabular}




\begin{tabular}{llll}
\hline Family \& Species & Resident/Migrant & Zone & Abundance \\
\hline Brown Noddy Anous stolidus & $\mathrm{M}, \mathrm{R}$ & $\mathrm{C}$ & $\mathrm{U}$ \\
Lesser Noddy Anous tenuirostris & $\mathrm{M}, \mathrm{R}$ & $\mathrm{C}$ & $\mathrm{U}$ \\
$\begin{array}{l}\text { Family Accipitridae } \\
\text { Brahminy Kite Haliastur indus }\end{array}$ & $\mathrm{R}$ & $\mathrm{C}, \mathrm{I}$ & $\mathrm{L}$ \\
Osprey Pandion haliaetus & $\mathrm{M}$ & $\mathrm{C}, \mathrm{I}$ & $\mathrm{R}$ \\
White-bellied Sea Eagle Haliaeetus leucogaster & $\mathrm{R}$ & $\mathrm{C}, \mathrm{I}$ & $\mathrm{U}$ \\
Marsh Harrier Circus aeroginosus & $\mathrm{M}$ & $\mathrm{I}$ & $\mathrm{U}$ \\
Pallid Harrier Circus macrourus & $\mathrm{M}$ & $\mathrm{I}$ & $\mathrm{U}$ \\
Montagu's Harrier Circus pygargus & $\mathrm{M}$ & $\mathrm{I}$ & $\mathrm{U}$ \\
Family Alcedinidae & & & \\
White-breasted Kingfisher Halcyon smyrnensis & $\mathrm{R}$ & $\mathrm{I}, \mathrm{C}$ & $\mathrm{C}$ \\
Common Kingfisher Alcedo atthis & $\mathrm{R}$ & $\mathrm{I}, \mathrm{C}$ & $\mathrm{U}$ \\
Pied Kingfisher Ceryle rudis & $\mathrm{R}$ & $\mathrm{C}, \mathrm{I}$ & $\mathrm{U}$ \\
Stork-billed Kingfisher Pelargopsis capensis & $\mathrm{R}$ & $\mathrm{C}, \mathrm{I}$ & $\mathrm{C}$ \\
\hline
\end{tabular}

Appendix 2: Some of the avian specialties in the northern region that were found to breed only in the present study area.

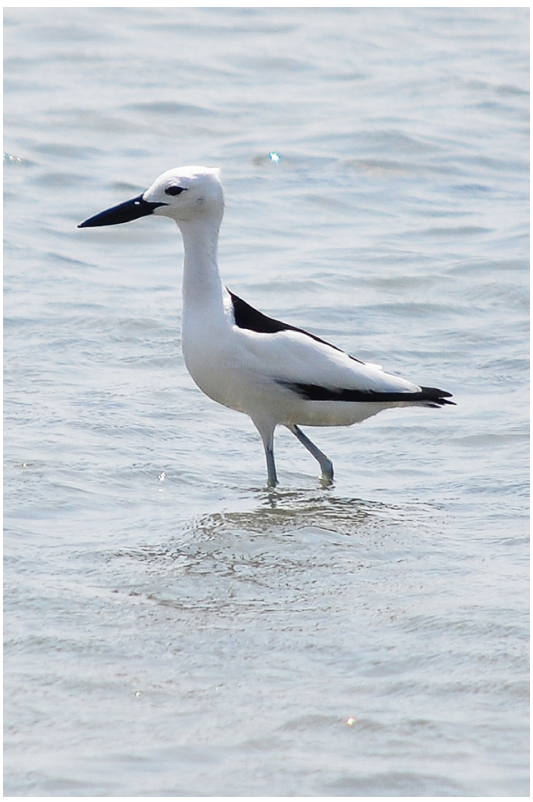

Crab Plover (Dromas ardeola), Vankalai Sanctuary, Mannar. Photograph by Chaminda S. Wijesundara.

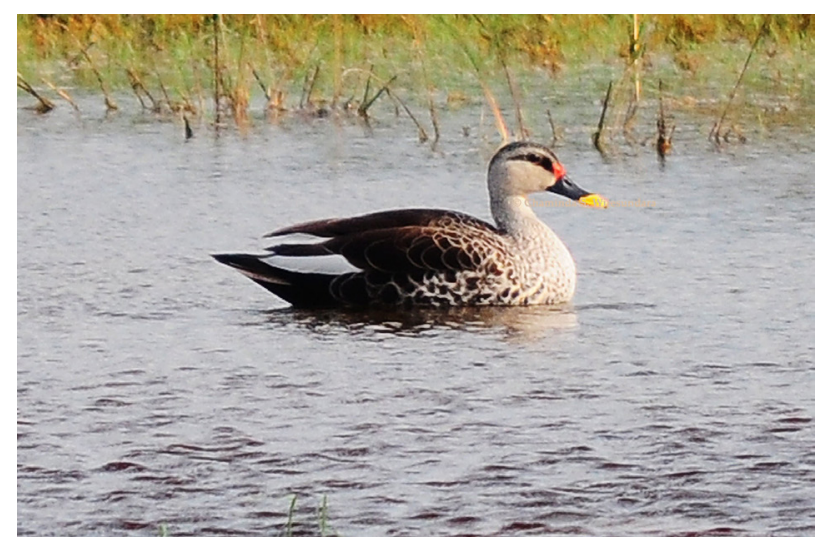

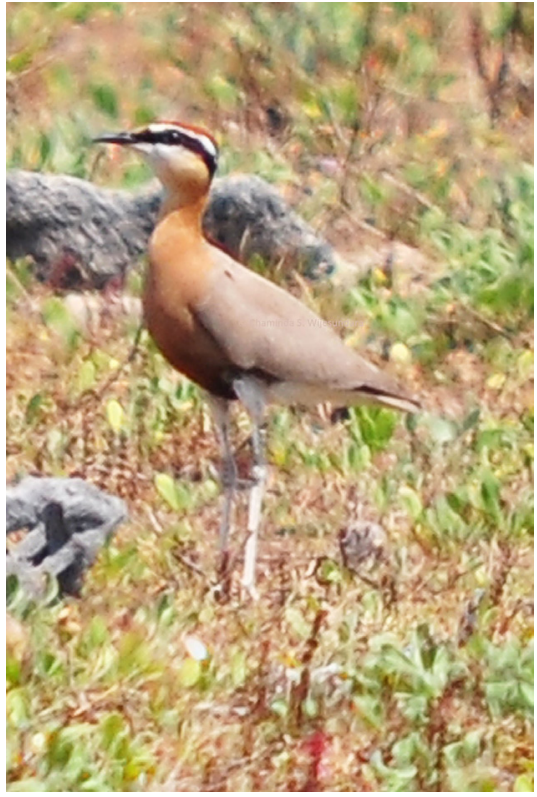

Indian Courser (Cursorius coromandelicus), Delft Island, Jaffna. Photograph by Chaminda S. Wijesundara.

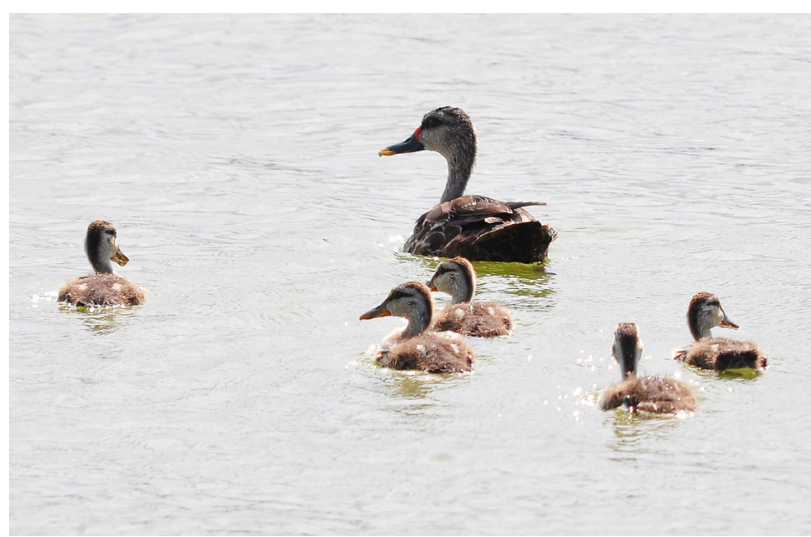

Left: Spot-billed Duck (Anas poecilorhyncha), Allaipiddy, Jaffna. Right: Spot-billed Duck with chicks at Araly Junction, Jaffna. Photographs by Chaminda S. Wijesundara. 